\title{
Anticancer Activity of Eleutherine bulbosa (Mill.) Urb. Extract on WiDr Cell Line In Vitro
}

\author{
Ichwan Alamsyah Lubis ${ }^{1}$, M. Ichwan ${ }^{2}$ \\ Department of Pharmacology \\ Faculty of Medicine, Universitas Sumatera Utara \\ Medan, Indonesia \\ ichwan.a.lubis@gmail.com,mhd.ichwan@gmail.com
}

\author{
Mustofa $^{3}$ \\ Department of Pharmacology \\ Faculty of Medicine, Gadjah Mada University \\ Yogyakarta, Indonesia \\ mustofafk@ugm.ac.id
}

\author{
Denny Satria ${ }^{4}$ \\ Department of Pharmaceutical Biology \\ Faculty of Pharmacy, Universitas Sumatera Utara \\ Medan, Indonesia \\ denny.satria.dennysatria@gmail.com
}

\begin{abstract}
Colon cancer is third of cancer cases that occur in the world's population. The incidence of new cases in men are 614.300 and women are 746.300 , while the death rate in men are 373.600 and in women are 320.300. Colon cancer treatments are surgery, chemotherapy, and radiotherapy. The problem with chemotherapy is trigger development of a new drug and among other from natural compound. The plant that is known to have cytotoxic activity against cancer cells are Eleutherine bulbosa (Mill.) Urb. This study aims to analysis the anticancer activity of Eleutherine bulbosa (Mill.) Urb. extract on WiDr cells. The research method includes gradual maceration using n-hexane, ethyl acetate, and ethanol, phytochemical analysis of extracts, cytotoxicity assay on WiDr cells with MTT (Microculture Tetrazolium Technique) assay, and selectivity index assay on WiDr and Vero cells. The MTT assay result show that Eleutherine bulbosa (Mill.) Urb. has cytotoxic activity on WIDr cells, but only ethyl acetate extract are selective. Further studies are to assess the mechanisms of ethyl acetate extracts in induce apoptosis, inhibit the cell cycle, and the expression of protein that associated with it.
\end{abstract}

Keywords- Eleutherine bulbosa (Mill.) Urb.; WiDr cell line; MTT assay; selectivity index

\section{INTRODUCTION}

Cancer is a disease with increasing number of mortality in humans. The world's leading death-causing cancers are breast, cervical, colon, lung, and stomach [1]

Global cancer stastistics reported that colon cancer is the third cancer cases in the world population, with the number of cases are 1.4 million and 693,900 deaths occured at 2012. Number of cases in men is higher than that of women with a new cases is 746,300 cases in men and 614,300 cases in women, that cause the number of mortality becomes 373,600 cases in men and 320,300 cases in women [2].

Treatment of colon cancer are consist of surgery, chemotherapy, and radiotherapy, depending on the stage of cancer patients [3]. Various treatments of colon cancer still have many weaknesses, such as resistance to chemotherapy drugs [4]. The problems with chemotherapy drugs are triggering the development of new drugs and the uses of medicines from natural compounds that have potential effect as chemotherapy drugs to overcome resistance of colon cancer treatment [5].

One of the plants that reported to have cytotoxic activity against cancer cells and may be developed to anticancer drug is Eleutherine bulbosa (Mill.) Urb. [6]. To analyze the anticancer, activity of a compound can be done by preliminary test using in vitro method [7]. In vitro method was performed using a colon cancer cell line. One of the colon cancer cell line that is frequently used in research is a WiDr cells, which is adenocarcinoma cells isolated from colon of 78-year-old female [8]. In the case of colon cancer, it is found that almost $96 \%$ of colon cancer is an adenocarcinoma which develops from gland cells [9].

Based on this background, researchers are interested in analyzing anticancer activity of Eleutherine bulbosa (Mill.) Urb. that was extracted by gradual maceration on the WiDr cells by cytotoxic assay method.

\section{MATERIALS AND METHODS}

\section{A. Preparation of Plant Material}

Eleutherine bulbosa (Mill.) Urb. was obtained from Simalingkar B Village, Medan Tuntungan, North Sumatera that was harvested when the plant age about 4 months. Eleutherine bulbosa (Mill.) Urb. is identified by Herbarium Medanense (MEDA), Universitas Sumatera Utara, Medan. And then, Eleutherine bulbosa (Mill.) Urb. dried in a drying cabinet with the temperature of $40-60^{\circ} \mathrm{C}$ until water content reaches below $10 \%$.

\section{B. Preparation of Crude Extract}

A total of 100 parts of the simplisia are inserted into the dark vessel, macerated with 75 parts of $n$-hexane, then closed and left for 5 days protected from light, often stirred. After 5 days, the solution was filtered and the dregs were washed with $n$-hexane to obtain 100 parts. The solution is accommodated on a dark bottle, left in a cool place and protected from light 
for 2 days. Then, filtered and evaporated the maserate with a rotary evaporator and dried with a freeze dryer. The powder is dried by aerated and re-macerated with ethyl acetate and ethanol with the same treatment as in the $n$-hexane solvent [10].

\section{Phytochemical Analysis}

Secondary metabolite information was obtained by performing phytochemical analysis on each extract which have different polarity. The secondary metabolites was examined are alkaloids, flavonoids, anthraquinones, saponins, glycosides, tannins, triterpenes, and steroids [11].

\section{Preparation of Crude Extract Stock Solution}

The crude extract was weighed at $5 \mathrm{mg}$, and was dissolved with DMSO at $5 \mathrm{ml}$ in microtube so the concentration of the solution are reaches $1 \mathrm{mg} / \mathrm{mL}$ and used as stock solution to be diluted using medium culture to obtain the concentration required for cytotoxicity assay.

\section{E. Cell Culture}

WiDr cells and Vero cells in this research were obtained from the Parasitology Laboratory, Faculty of Medicine, Gadjah Mada University. The WiDr cells is grown on RPMI medium containing Fetal Bovine Serum 10\% (Gibco, USA), Penicillin-Streptomycin 2\% (Gibco, USA), and Fungizone $0.5 \%$ (Amphotericin B) (Gibco, USA). Vero cells were grown in M199 medium containing Fetal Bovine Serum 10\% (Gibco, USA), Penicillin-Streptomycin 2\% (Gibco, USA), and Fungizone $0.5 \%$ (Amphotericin B) (Gibco, USA). Cells were grown on a flask in the incubator $\left(5 \% \mathrm{CO}_{2}\right.$ and $95 \%$ air $)$ with a temperature at $37^{\circ} \mathrm{C}$ [12].

\section{F. MTT Assay}

MTT assay is used to assess the viability of both WiDr and Vero cells. The cells were grown on a 96 well plate (Iwaki, Japan). In each well contains $1 \times 10^{4}$ cells. Cells were incubated in incubators $\left(5 \% \mathrm{CO}_{2}\right.$ and $95 \%$ air) at $37^{\circ} \mathrm{C}$ for 24 hours. After 24 hours incubation, the medium was discarded and the cells on a 96 well plate were tested on each extract with a minimal of five serial concentration and incubation for 24 hours. After incubation for $24 \mathrm{~h}$, the medium culture was discarded and MTT was added on to the cells with the concentration is $0.5 \mathrm{mg} / \mathrm{mL}$ (Sigma-Aldrich, USA) and incubation for 4 hours. The living cell reacts with MTT to produce of purple crystals formazan. After 4 hours, 10\% SDS (Sigma-Aldrich, USA) stopper solution was added in $0.01 \mathrm{~N}$ $\mathrm{HCl}$ (Merck, USA) to dissolve the formazan crystals. The cells are reincubated for 24 hours at room temperature and wrapped to avoid light. After incubation is complete, measured of cells absorbance with microplate reader (Bio-Rad) at $\lambda 595 \mathrm{~nm}$.

The absorbance data of each well, then converted to percentage of viable cell using this equation

$$
\% \text { of viable cells }=(\mathrm{B}-\mathrm{C}) /(\mathrm{A}-\mathrm{C}) \times 100 \%
$$

Where A, B, and C (1) respectively are the absorbance of the control group, treatment group and medium culture group. All data were used to calculate $\mathrm{IC}_{50}$ value which was analyzed by using probit regression method using SPSS 20 [13].

\section{G. Selectivity Index}

The selectivity index was calculated from the ratio of normal cells (Vero cells) $\mathrm{IC}_{50}$ value compared to cancer cells (WiDr cells) $\mathrm{IC}_{50}$ value using this equation [14].

$$
\begin{gathered}
\mathrm{SI}=\text { Vero cells } \mathrm{IC}_{50} / \mathrm{WiDr} \text { cells } \mathrm{IC}_{50} \\
\qquad \alpha+\beta=\chi .
\end{gathered}
$$

\section{RESULT}

\section{A. Phytochemical Analysis}

The results of phytochemical analysis will be used as a reference for identifying classes of secondary metabolite compounds that are active as anticancer substances on WiDr cells. The results of phytochemical analysis of $n$-hexane, ethyl acetate, and ethanol extract are shown in Table 1.

TABLE I. PHYTOCHEMICAL ANALYSIS OF EXTRACT

\begin{tabular}{|l|c|c|c|}
\hline \multirow{2}{*}{$\begin{array}{c}\text { Metabolite } \\
\text { Compound }\end{array}$} & \multicolumn{3}{|c|}{ extract } \\
\cline { 2 - 4 } & n-hexane & ethyl acetate & ethanol \\
\hline Alkaloids & - & + & + \\
\hline Flavonoids & - & + & + \\
\hline Glycosides & - & + & + \\
\hline Saponins & - & + & + \\
\hline Anthraquinones & - & + & + \\
\hline Tanins & - & - & + \\
\hline Triterpenoids & + & + & + \\
\hline Steroids & + & + & + \\
\hline
\end{tabular}

\section{B. Cytotoxicity Assay}

The paramater is used to know of the potential toxicity of a compound is by doing the cytotoxic assay. The effect of each extract on WiDr cells viability shown in Fig. 1.

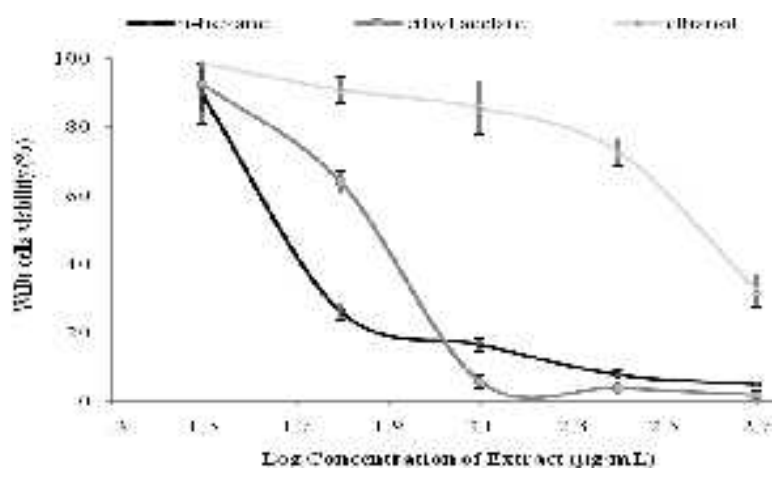

Fig. 1. Graph of $\log$ concentration of extract on WiDr cells viability 
Based on Fig. 1, the cytotoxic activity on the WiDr cells is calculated to obtain $\mathrm{IC}_{50}$ value of each extract shown at Table 2.

TABLE II. $\quad$ IC $_{50}$ VALUE OF EACH EXTRACT ON WiDr CELLS

\begin{tabular}{|l|c|}
\hline \multicolumn{1}{|c|}{ Extract } & IC $_{\mathbf{5 0}}$ value $^{\mathbf{a}}(\boldsymbol{\mu g} \mathbf{g} \mathbf{m L})$ \\
\hline$n$-hexane & $56.145 \pm 3.539$ \\
\hline ethyl acetate & $70.758 \pm 7.702$ \\
\hline ethanol & $364.103 \pm 31.169$ \\
\hline
\end{tabular}

Cytotoxic assay on Vero cells are only performed by extracts that have strong cytotoxic activity $\left(\mathrm{IC}_{50}\right.$ value on WiDr cells $<100 \mathrm{~g} / \mathrm{mL}$ ). The effect of each extract on Vero cells viability shown in Fig. 2.

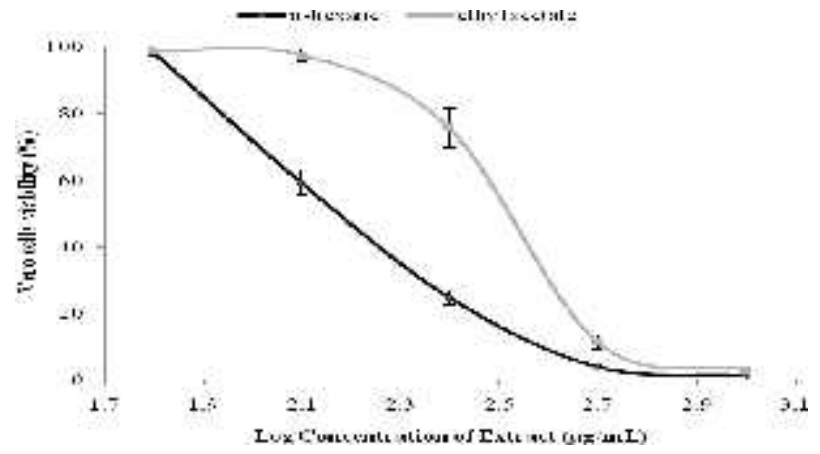

Fig. 2. Graph of log concentration of extract on Vero cells viability

Based on Fig. 2, the cytotoxic activity on Vero cells is calculated to obtain $\mathrm{IC}_{50}$ value of each extract shown at Table 3.

TABLE III. $\quad$ IC $_{50}$ VALUE OF EACH EXTRACT ON VERO CELLS

\begin{tabular}{|l|c|}
\hline \multicolumn{1}{|c|}{ Extract } & IC $_{\mathbf{5 0}}$ value $^{\text {a }}(\boldsymbol{\mu g} / \mathbf{m L})$ \\
\hline$n$-hexane & $162.291 \pm 8,336$ \\
\hline ethyl acetate & $323.171 \pm 12,821$ \\
\hline & a. Expressed in mean value $(\mathrm{n}=3) \pm$ Standard Deviation \\
\hline
\end{tabular}

\section{Selectivity Index}

Selectivity index is a safety parameter of an extract against normal cells. The results of selectivity index of each extract on WiDr cells are shown in Table 4.

TABLE IV. SELECTIVITY INDEX VALUE

\begin{tabular}{|l|c|}
\hline \multicolumn{1}{|c|}{ Extract } & Selectivity Index \\
\hline$n$-hexane & 2.89 \\
\hline ethyl acetate & 4.57 \\
\hline
\end{tabular}

\section{DISCUSSION}

The results of phytochemical analysis showed that nhexane extract contains secondary metabolite compound of triterpenoid/steroid. Ethyl acetate extract contains secondary metabolite compounds of flavonoids, glycosides, saponins, anthraquinones, and triterpenoids/steroids. Ethanol extract contains secondary metabolite compounds class of alkaloids, flavonoids, glycosides, saponins, anthraquinones, tannins, triterpenoids. The cytotoxic effect of Eleutherine bulbosa (Mill.) Urb. on various cancer cells are thought to be caused by the secondary metabolites of flavonoids, anthraquinones, and triterpenoids contained in these plants. Eleutherine bulbosa (Mill.) Urb. containing the quinone group compound of naphthaquinone and some of its species are isoeleutherin, eleutherin and eleutherol [15]. The naphthaquinone and derivatives are soluble in non polar solvents such as n-hexane and chloroform [16]. Eleutherin is known to be cytotoxic to colon cancer cells HT-29, HCT-116, COLO-25, erythroleukemia cancer cells K562 and cervical cancer cells HeLa [17-19].

In the cytotoxic test results, $\mathrm{IC}_{50}$ extract of n-hexane, ethyl acetate extract and ethanol extract were respectively $56.145 \pm$ $3.539 \mathrm{~g} / \mathrm{mL}, 70.758 \pm 7.702 \mathrm{~g} / \mathrm{mL}, 364.103 \pm 31.169 \mathrm{~g} /$ $\mathrm{mL}$. The extract of $n$-hexane and ethyl acetate from Eleutherine bulbosa (Mill.) Urb. has strong cytotoxic activity, whereas ethanol extract has only moderate cytotoxic activity. The extract can be said to have strong cytotoxic activity when $\mathrm{IC}_{50}$ values are $10-100 \mathrm{~g} / \mathrm{mL}$ and moderate cytotoxic activity if $\mathrm{IC}_{50}$ value are $100-500 \mathrm{~g} / \mathrm{mL}$ [14]. Cytotoxicity assay of each extract from Eleutherine bulbosa (Mill.) Urb. was performed by MTT method [3- (4,5-dimethyltiazole-2-yl) 2,5-diphenyl tetrazolium bromide] which is one of the quantitative cytotoxicity assay. This test is based on the measurement of the color intensity (colorimetry) that occurs as a result of the metabolism of a substrate by living cells into colored products. In this test, tetrazolium salt MTT is used. This tetrazolium salt MTT will be involved in the work of dehydrogenase enzymes. Tetrazolium salt MTT will be reduced to formazan crystal by succinic- tetrazolium reductase system, which is included in the mitochondria of living cells [20].

Triterpenoid/steroid compounds has anticancer activity by inhibiting the expression of the nuclear factor kappa-B (NF$\mathrm{kB}$ ), inducing apoptosis, and inhibiting the expression of proteins involved in angiogenesis and cancer cell metastasis [21].

The isolated naphthaquinone compounds has cytotoxic activity on leukemia cells RAW 264.7 by inhibiting the production of nitric oxide induction enzyme (iNOS), iNOS plays a role in increasing the activity of NF-KB in cancer incidence. Inhibition of iNOS production will decrease NF$\mathrm{KB}$ activity which will eventually cause cells to undergo apoptosis [22]. Naphtoquinones also has antiproliferative and cytotoxic activity on colon cancer and cervix cancer [23, 24].

Flavonoids have been used as disease prevention and therapeutic agents in traditional medicine in Asia, one of them as anticancer [25]. Flavonoid compounds work by inhibiting proliferation through inhibition of oxidative processes that can lead to cancer initiation. Flavonoids inhibit the expression of topoisomerase I and topoisomerase II enzymes that play a role in catalysis of playback and relaxation of DNA. Topoisomerase enzyme inhibitors will stabilize the topoisomerase complex and cause the DNA to be cut and 
damaged and induce cell to undergo apoptosis. Flavonoids have been shown to inhibit proliferation in various models of cancer cells $[26,27]$.

The class of anthraquinone compounds has cytotoxic activity on colon cancer cells COLO 320 through the activation mechanism of $\mathrm{p} 53$ protein, $\mathrm{p} 53$ protein will increase the expression of proapoptotic protein families such as Bax and suppress the expression of antiapoptotic proteins such as Bcl-2 which will induce apoptosis [28]. The process of occurrence apoptosis can occur through two lines of the pathway, from the cell outside (extrinsic) and from the mitochondrial stress (intrinsic). Both the extrinsic pathway and the intrinsic pathway will end in the execution phase by activating the caspase cascade which is the final path of apoptosis [29]. The anthraquinone group compounds are thought to cause apoptosis either through extrinsic or intrinsic pathways with the activation of caspase cascade [30].

Anthraquinone also works by increasing the intracellular production of ROS (reactive oxidative species) in HCT-116 colon cancer cell model, increasing ROS will trigger an increase in p53 expression due to oxidative stress response. Increased p53 protein can lead to apoptosis through an intrinsic pathway, p53 protein plays an important role in the regulation of Bcl-2 antiapoptosis and proapoptosis protein families, excessive expression of p53 results in increased expression of proapoptotic proteins such as Bax and decreased expression of antiapoptotic proteins such as Bcl-2, changes in expression in the Bcl-2 family will alter the permeability of mitochondrial membranes that will regulate the release of Cytochrome-c from mitochondria. Cytochrome-c in the cytosol is binds and activates Apaf-1 and procaspase-9, forming an apoptosome that will activate caspase cascade and eventually cause apoptosis [31]. In the extrinsic pathway, the anthraquinone compound induces death ligand to bind to death receptor, thus modulating procaspase- 8 which then forms a death-inducing signaling complex (DISC). This complex causes activated caspase-8, which will activating caspase-3 [32].

To assess the selectivity of an extract against cancer cells can be calculated the selectivity index value, by compare the $\mathrm{IC}_{50}$ value of Vero cells to $\mathrm{IC}_{50}$ value of WiDr cells. The extract is said to have high selectivity if the selectivity index value is greater than 3 , so it can be said that the $n$-hexane extract is less selective against the WiDr cells while the ethylacetate extract is selective against WiDr cells [33].

\section{CONCLUSION}

Eleutherine bulbosa (Mill.) Urb.) has cytotoxic activity on WiDr cells, in which $n$-hexane extract has the strongest cytotoxic activity compared with both ethylacetate and ethanol extracts. However, $n$-hexane extract is less selective against WiDr cells compared with ethylacetate extract. We suggest to do further research to assess the mechanisms of ethyl acetate extract in induce apoptosis, inhibition of cell cycle, and to observe the expression of the proteins associated with it.

\section{ACKNOWLEDGMENT}

Thanks to the staff of the Parasitology Laboratory, Gadjah Mada University, Yogyakarta who has assisted this research until finish. May all of your help will be rewarded from Allah Almighty.

\section{REFERENCES}

[1] N. S. Yaacob, et al., "Anticancer activity of a sub-fraction of dichloromethane extract of Strobilanthes crispus on human breast and prostate cancer cells in vitro," BMC Complementary and Alternative Medicine, vol. 10, p. 42, 2010.

[2] L. A. Torre, F. Bray, R. L. Siegel, J. Ferlay, J. Lortet-Tieulent, and A. Jemal, "Global cancer statistics, 2012," CA: A Cancer Journal for Clinicians, vol. 65, pp. 87-108, 2015.

[3] R. Dienstmann, R. Salazar, and J. Tabernero, "Personalizing colon cancer adjuvant therapy: selecting optimal treatments for individual patients," Journal of Clinical Oncology, vol. 33, pp. 1787-1796, 2015.

[4] S. Raguz and E. Yagüe, "Resistance to chemotherapy: new treatments and novel insights into an old problem," British Journal of Cancer, vol. 99 , p. 387, 2008.

[5] S. Bent, "Herbal medicine in the United States: review of efficacy, safety, and regulation," Journal of General Internal Medicine, vol. 23, pp. 854-859, 2008.

[6] C. L. Couto, D. F. Moraes, S. C. Maria do Socorro, agenes, F. M. do Amaral, and R. N. Guerra, "Eleutherine bulbous (Mill.) Urb.: a review study," Journal of Medicinal Plants Research, vol. 10, pp. 286-297, 2016.

[7] B. A. Teicher, Anticancer Drug Development Guide: Preclinical Screening, Clinical Trials, and Approval. New York: Springer Science \& Business Media, 2013.

[8] T. Chen, D. Drabkowski, R. Hay, M. Macy, and W. Peterson, "WiDr is a derivative of another colon adenocarcinoma cell line, HT-29," Cancer Genetics and Cytogenetics, vol. 27, pp. 125-134, 1987.

[9] S. L. Stewart, J. M. Wike, I. Kato, D. R. Lewis, and F. Michaud, "A population-based study of colorectal cancer histology in the United States, 1998-2001," Cancer, vol. 107, pp. 1128-1141, 2006.

[10] Y. Fitri and E. S. Rosidah, "Effects of inhibition cell cycle and apoptosis of sabrang onion extract (Eleutherine bulbosa (Mill.) Urb.) on breast cancer cells," International Journal of PharmTech Research, vol. 6, pp. 1392-1396, 2014.

[11] R. N. Prasad, et al., "Preliminary phytochemical screening and antimicrobial activity of Samanea saman," Journal of Medicinal Plants Research, vol. 2, pp. 268-270, 2008.

[12] A. Doyle and J. B. Griffiths, Tissue Culture : Laboratory Procedure in Biotechnology. Chichester: Wiley, 1998.

[13] E. Meiyanto, R. A. Susidarti, S. Handayani, and F. Rahmi, "Ekstrak etanolik biji buah pinang (Areca catechu L.) mampu menghambat proliferasi dan memacu apoptosis sel MCF-7," Majalah Farmasi Indonesia, vol. 19, pp. 12-19, 2008.

[14] S. Machana, N. Weerapreeyakul, S. Barusrux, A. Nonpunya, B. Sripanidkulchai, and T. Thitimetharoch, "Cytotoxic and apoptotic effects of six herbal plants against the human hepatocarcinoma (HepG2) cell line," Chinese Medicine, vol. 6, p. 39, 2011.

[15] S. Paramapojn, M. Ganzera, W. Gritsanapan, and H. Stuppner, "Analysis of naphthoquinone derivatives in the Asian medicinal plant Eleutherine americana by RP-HPLC and LC-MS," Journal of Pharmaceutical and Biomedical Analysis, vol. 47, pp. 990-993, 2008.

[16] L. C. da Silva Malheiros, J. C. P. de Mello, and W. L. R. Barbosa, "Eleutherine Plicata-Quinones and Antioxidant Activity," in Phytochemicals-Isolation, Characterisation and Role in Human Health, ed London: InTech, 2015.

[17] M. Ali Yusni, "Perbedaan pengaruh pemberian fraksi etanolik bawang dayak (Eleutherine Palmifolia L. Merr) dengan 5-Fluorouracil terhadap penghambatan pertumbuhan galur sel karsinoma kolon HT29 dan Ekspresi p53 Mutan," Universitas Sebelas Maret Surakarta, 2008. 
[18] M. Insanu, S. Kusmardiyani, and R. Hartati, "Recent studies on phytochemicals and pharmacological effects of Eleutherine americana Merr," Procedia Chemistry, vol. 13, pp. 221-228, 2014.

[19] S. Baikar and N. Malpathak, "Secondary metabolites as DNA topoisomerase inhibitors: a new era towards designing of anticancer drugs," Pharmacognosy Reviews, vol. 4, p. 12, 2010.

[20] L. Kupcsik, "Estimation of cell number based on metabolic activity: the MTT reduction assay," in Mammalian Cell Viability, ed New York: Springer, 2011, pp. 13-19.

[21] A. Petronelli, G. Pannitteri, and U. Testa, "Triterpenoids as new promising anticancer drugs," Anti-Cancer Drugs, vol. 20, pp. 880-892, 2009.

[22] S.-H. Song, et al., "Suppression of inducible nitric oxide synthase by (-)-isoeleutherin from the bulbs of Eleutherine americana through the regulation of NF- $\kappa \mathrm{B}$ activity," International Immunopharmacology, vol. 9, pp. 298-302, 2009.

[23] P. Babula, V. Adam, L. Havel, and R. Kizek, "Noteworthy secondary metabolites naphthoquinones-their occurrence, pharmacological properties and analysis," Current Pharmaceutical Analysis, vol. 5, pp. 47-68, 2009

[24] T. M. A. Alves, H. Kloos, and C. L. Zani, "Eleutherinone, a novel fungitoxic naphthoquinone from Eleutherine bulbosa (Iridaceae)," Memorias do Instituto Oswaldo Cruz, vol. 98, pp. 709-712, 2003.

[25] C. Kanadaswami, L.-T. Lee, P.-P. H. Lee, J.-J. Hwang, F.-C. Ke, Y.-T. Huang, et al., "The antitumor activities of flavonoids," In Vivo, vol. 19 pp. 895-909, 2005.
[26] W. Ren, Z. Qiao, H. Wang, L. Zhu, and L. Zhang, "Flavonoids promising anticancer agents," Medicinal Research Reviews, vol. 23, pp. 519-534, 2003.

[27] M. K. Chahar, N. Sharma, M. P. Dobhal, and Y. C. Joshi, "Flavonoids: a versatile source of anticancer drugs," Pharmacognosy Reviews, vol. 5, p. $1,2011$.

[28] C. Balachandran, et al., "Isolation and characterization of anthraquinone from Streptomyces sp. ERINLG-26 with anticancer activity against adenocarcinoma cell line COLO320," Applied Biochemistry and Microbiology, vol. 51, pp. 522-529, 2015.

[29] Z. Hongmei, "Extrinsic and intrinsic apoptosis signal pathway review," in Apoptosis and Medicine, ed London: Intech, 2012.

[30] M. Genov, et al., "Tetrahydroanthraquinone derivative ( \pm )-4deoxyaustrocortilutein induces cell cycle arrest and apoptosis in melanoma cells via upregulation of p21 and p53 and downregulation of NF-kappaB," Journal of Cancer, vol. 7, p. 555, 2016

[31] M.-J. Xie, et al., "Emodin-provoked oxidative stress induces apoptosis in human colon cancer HCT116 cells through a p53-mitochondrial apoptotic pathway," Asian Pacific Journal of Cancer Prevention, vol. 15, pp. 5201-5205, 2014.

[32] B. Alberts, Molecular Biology of The Cell, 6th ed. New York: Garland Science, 2017

[33] N. Weerapreeyakul, A. Nonpunya, S. Barusrux, T. Thitimetharoch, and B. Sripanidkulchai, "Evaluation of the anticancer potential of six herbs against a hepatoma cell line," Chinese Medicine, vol. 7, p. 15, 2012. 